Journal of Social Sciences (COES\&RJ-JSS)

ISSN (E): 2305-9249 ISSN (P): 2305-9494

Publisher: Centre of Excellence for Scientific \& Research Journalism, COES\&RJ LLC

Online Publication Date: $1^{\text {st }}$ January 2021

Online Issue: Volume 10, Number 1, January 2021

https://doi.org/10.25255/jss.2021.10.1.48.58

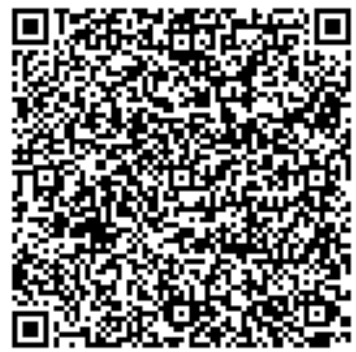

\title{
The Effect of Corporate Social and environmental Responsibility on
} Leverage and Performance: Evidence from Jordan

Lamees Talal Al-Radaydeh, Master of accounting

Dr. Manal Sulieman Abughniem, Accounting department, Applied Science

Private University, Amman, Jordan, manalabugh@yahoo.com

Dr. "Mohammad Adnan" Hilal Al Aishat, Accounting department, Al-Balqa

Applied University, Amman, Jordan, mohammadaishat@yahoo.com

Dr. Rania Al Omari, Department of Accounting, Faculty of Business,

http://orcid.org/0000-0003-1034-6200

Abstract:

This study aimed to test the effect of corporate social responsibility through activities towards society and environmental activities on financial leverage and corporate performance, the study population consists of all companies listed on the Amman Stock Exchange. The study sample reached 187 companies for the period 2014-2017, to achieve the goals of the study; regression analysis was used to find out the effect of social and environmental responsibility on leverage and performance, the study reached the results that the social responsibility towards the society affects the financial leverage of the company while the environmental activities did not affect the financial leverage, responsibility for social and environmental activities did not affect the performance of companies, and there was a positive correlation between social and environmental responsibility and financial leverage, and a negative link was found between financial leverage and performance.

Keyword:

Social Responsibility, Environmental Responsibility, Leverage, Performance Citation:

Al-Radaydeh, Lamees Talal; Abughniem, Manal Sulieman; Al-Aishat, "Mohammad Adnan" Hilal; Al-Omari, Rania (2021); The Effect of Corporate Social and

This work is licensed under a Creative Commons Attribution 4.0 International License. 
environmental Responsibility on Leverage and Performance: Evidence from Jordan; Journal of Social Sciences (COES\&RJ-JSS), Vol.10, No.1, pp:48-58; https://doi.org/10.25255/jss.2021.10.1.48.58.

\section{Introduction}

As a result of the development in the economic life, the development of companies and the increase in their activities, the society needs have evolved, and many accounting ideas have emerged and have evolved to confront the change in the economic environment. Where the concept of social responsibility appeared (Jerboa, 2007) and on the basis that accounting is a system that interacts with the environment, the idea of corporate social responsibility stems from its responsibility towards the external environment (Al-Amiri and Al-Ghalibi, 2008), social responsibility, in its broad and comprehensive concept, includes the commitment to achieve balance between multiple parties, but they are interrelated, represented by the interests and needs of each of the productive companies and their employees and the external environment and society.

It has been observed that there is an increased interest on the part of companies at the present time in their various activities towards fulfilling social responsibility to respond to the demands of society (Bremner, 2009), as companies implement social responsibility and achieve their goals: Improving the corporate image in society, and to enhance the morale of its employees, and improvement in employee retention rates within the company, building good relationships with government and the community and responding to social expectations (Henderson, 2007), the concept of social responsibility is one of the things companies care about and fall within their practice, because investing in social responsibility activities is an important issue that must be taken into consideration by companies, especially financial leverage and corporate performance.

Several studies have addressed activities related to social responsibility and its impact on performance, and accordingly, there is a need to ascertain how companies participate in social and environmental responsibility activities that may affect the financial leverage and performance of these companies, therefore, this study came to know the effect of social responsibility on the financial leverage and performance of companies listed on the Amman Stock Exchange.

\section{Previous studies}

A study of Dam and Scholtens, (2013) demonstrated a negative impact of ownership focus on CSR policies, while Harjoto and Jo, (2011) the presence of a positive impact of the factors of corporate governance and the disclosure of 
social responsibility on the operational performance and the value of companies, as for the study of $\mathrm{Hu}$, et al., (2016), it concluded that companies invest in companies that disclose social responsibility, a study of Saleh, et al. (2010) assumed that there was a relationship between social responsibility with the social and environmental dimension and institutional ownership, in contrast Ghoula et al, (2011). Examining the relationship between the practice of social responsibility activities by a sample of American companies and the cost of ownership, the study concluded that the companies that had a high degree of social responsibility activities had a low cost of ownership, Mwangi and Jerotich, (2013) conducted a study on the companies listed on the Nairobi Stock Exchange within the industrial and services sectors, and the study concluded that there is a strong correlation between social responsibility and the return on assets index.

Obby et al, (2018) in his study about the potential for critical collaboration at the local level is further challenged by the lack of commonly accepted social and environmental frameworks, transparency and accountability of the leadership of stakeholder groups, Sunghee and, Heungjun, (2016) the results of the analysis demonstrate that the positive relationship between CSR and financial performance, Hichem et.al (2015)association between performance and corporate social and environmental disclosuresocially responsible activities have been shown to create competitive advantage by building reputation, and differentiating products (Boehe and Cruz, 2010; Jung and Kim, 2015, Cruz et al., 2015) suggested that having a differentiation strategy helps market position and long-term returns, Ramanathan and Akanni (2015) provided evidence of the moderating role of organizational efficiency in the link between environmental performance and performance.

As for the study of the Mobaideen and Al-Dhahrawi (2017), results have shown that there is an effect of disclosing the costs of social responsibility related to environmental protection and community service on financial performance. As for the study Hirigoyen \& Rehm, (2015), the results showed that increasing social responsibility does not lead to improving financial performance, but that financial performance negatively affects corporate social responsibility. While a study Hossain et al, (2006) examined the relationship between the disclosure of social and environmental information and the many characteristics of companies in Bangladesh, the results showed that companies in Bangladesh had the lowest levels of social and environmental disclosure, and as for the study Rashi and Tariq (2013), this study aimed to show the benefits that the business organization reaps from adopting the concept of social responsibility. The study concluded that the social responsibility of business companies is a theoretical and field reality, while Tamkeen for Studies and Research, (2007) the study showed about the development of corporate social responsibility in the Kingdom of Saudi Arabia. 
The concept of corporate social responsibility in the Kingdom is still linked to charitable work, and Rahahleh and Sharair (2008) concluded that there is no full understanding of the concept of social responsibility accounting in companies operating in the industrial city of Al-Hassan in Jordan, there is a limited application of social responsibility accounting in it. As the application was confined mainly to the field of environmental protection, whereas Jain et al., (2007) in their study showed that there is an increasing need to emphasize the importance of social responsibility by companies and that corporate management for good social activity is an indication of the efficiency of management at work, as for the study Katsioloudes (2007), it concluded that there is awareness among companies in the United Arab Emirates and that they perform well in the areas of social responsibility mentioned above, and that neglecting this responsibility is harmful to the financial and commercial performance of the company.

A study of Guthrie et al, (2008) discussed the development of a social and environmental reporting framework for the Australian food and beverage industry as well as an assessment of the social and environmental reports of companies within the industry where the results indicated that there are more disclosed Australian reports according to the companies. In a particular industry in the area of social and environmental reporting, and that there is a need to add industry-specific disclosure items, whereas Fauzi et al, (2007) the study found that there is no statistically significant relationship between the social performance of companies and the financial performance of companies. As for the study Ndemanga \& Koffi (2009) studied whether there is an effect of the ownership structure on the CSR activities of the listed companies on the Stockholm Stock Exchange and state-owned companies, the study concluded that there is a strong direct relationship for some sectors on environmental performance, and the study of Farah and Al-Hindawi (2011) aimed at researching the extent of disclosure of elements of social responsibility in the annual financial reports for Jordanian Industrial Public Shareholding Companies, and explaining the impact of the size of the assets and sales volume on the degree of disclosure. The study used a content analysis method to the extent of disclosure in the financial reports, and there was a discrepancy in the level of disclosure of elements of social responsibility between companies.

\section{Research Methodology}

The sample is based on for companies listed on Amman Stock Exchange 187 companies' over the period of 4 years (from 2014 to 2017). A total of 2992 observations variable is present in the study, the researchers eliminated companies whose data is not fully elaborate. The study focuses on measuring the 
impact of social responsibility, which consists of activities related to community service and the development of environmental resources and the impact of this on financial performance and indebtedness Hirigoyen \& Rehm (2015), Sunghee and Heungjun, (2016), and (Hichem et.al (2015). The study variables were also measured by obtaining them from the annual reports of companies listed on the Amman Stock Exchange to disclose social and environmental activities.

Leverage: is measured by the ratio of the debt divided by the total assets, Performance: is measured by the Return on Assets (ROA) is measured by the ratio of the net profit divided by the total assets.

Model specification: The model is stated in its implicit form below as follows:

The estimation approach leads to the following estimation equations:

LEVit $=\mathrm{B}_{0}+$ SOCit + ENVit+size $+\mathrm{m}:(1)$

PERFit $=\mathrm{B}_{0}+\mathrm{SOC}$ it+ENVit+size $+\mathrm{m}:(2)$

\section{Descriptive Statistics}

Table 1 presents descriptive statistics of the independent study variables, social and environmental activities, and table (2) variables related to leverage and corporate performance.

\begin{tabular}{lccl}
\hline \multicolumn{3}{l}{ Table (1) Descriptive Statistics } & \\
\hline & $\mathrm{N}$ & Mean & $\begin{array}{l}\text { Std. } \\
\text { Deviation }\end{array}$ \\
\hline Social activity & 748 & .6270 & .48392 \\
environmental activity & 748 & .5307 & .49939 \\
Valid N (list wise) & 748 & & \\
\hline
\end{tabular}

Table 1 shows that the highest level of disclosure for the social and environmental activities of companies listed on the Amman Stock Exchange with a level of disclosure (62.7\%), it is clear that the companies have a good level of disclosure for social and environmental activities, where the percentages are higher than 50\%, and this indicates an increased interest and awareness of companies with these activities

Table (2)Descriptive Statistics

\begin{tabular}{llllll}
\hline & $\mathrm{N}$ & Minimum & Maximum & Mean & Std. Deviation \\
\hline Debt ratio & 748 & 0.09 & 104.24 & 36.34 & 27.611 \\
performance & 748 & -483.28 & 38.67 & 0.088 & 20.734 \\
size & 748 & 5.14 & 10.41 & 7.537 & 0.793 \\
Tq & 748 & 0.02 & 7.22 & 0.689 & 0.741 \\
Valid N (listwise) & 748 & & & & \\
\hline
\end{tabular}


Table (2) shows that descriptive analysis of the variables of the study. Where the arithmetic average of the dependent and control variable was reached, Leverage (36.34), and the standard deviation value reached (27.611), Moreover, the Performance was0 (.088), and the standard deviation value reached (20.734).

\begin{tabular}{|c|c|c|c|c|c|}
\hline & social responsibility & environmental & leverage & performance & size \\
\hline social activity & 1 & & & & \\
\hline environmental activity & $.615^{* *}$ & 1 & & & \\
\hline Debt ratio & $.245^{* *}$ & $.166^{* *}$ & 1 & & \\
\hline performance & .065 & .035 & $-.098 * *$ & 1 & \\
\hline size & $346^{* *}$ & $296 * *$ & $.604^{* *}$ & $.192^{* *}$ & 1 \\
\hline \multirow[t]{2}{*}{$\mathrm{Tq}$} & .027 & -.065 & $-.343^{* *}$ & $-.236^{* *}$ & $-.353^{* *}$ \\
\hline & N 748 & 748 & 748 & 748 & 748 \\
\hline
\end{tabular}

Table 3 shows the correlation matrix for the independent, dependent and control study variables. We note from the above table that there is a correlation between social responsibility and environmental activities at a level of (1\%) of $\left(0.615^{* *}\right)$, and the correlation between social and leverage amounted to $(0.245$ $\left.{ }^{* *}\right)$, while the percentage of correlation was low and positive between performance and both social and environmental activities, and it was low and negative between performance and debt.

\section{Test the hypotheses of the study}

Regression analysis was conducted to identify the impact of social responsibility on both the indebtedness and performance of companies listed on the Amman Stock Exchange.

\begin{tabular}{|c|c|c|c|c|c|}
\hline \multicolumn{6}{|c|}{$\begin{array}{l}\text { Table (4) Multiple Regression Test Results forEffect of corporate social responsibility on leverage } \\
\text { companies listed on Amman stock exchange }\end{array}$} \\
\hline \multirow[t]{3}{*}{ Model } & \multirow{2}{*}{\multicolumn{2}{|c|}{$\begin{array}{l}\text { Unstandardized } \\
\text { Coefficients }\end{array}$}} & \multirow{3}{*}{$\begin{array}{l}\text { Standardized } \\
\text { Coefficients } \\
\text { Beta }\end{array}$} & \multirow[t]{3}{*}{$\mathrm{t}$} & \multirow[t]{3}{*}{ Sig. } \\
\hline & & & & & \\
\hline & B & Std. Error & & & \\
\hline (Constant) & 27.403 & 1.638 & & 16.728 & .000 \\
\hline socialactivity & 13.133 & 2.571 & .230 & 5.109 & .000 \\
\hline environmental a ctivity & 1.323 & 2.491 & .024 & .531 & .595 \\
\hline Mod & $\mathrm{R}$ & Adjusted $\mathrm{R}$ & Std. Error of the & $\mathrm{F}$ & Sig. \\
\hline el & Square & Square & Estimate & & \\
\hline 246 & .060 & .058 & 26.80111 & 23.917 & .000 \\
\hline \multicolumn{6}{|l|}{ a. Dependent Variable: leverage } \\
\hline
\end{tabular}

Table 4 shows that the level of significance of the impact of disclosure of social responsibility activities on indebtedness in companies listed on the Amman Stock Exchange reached $(.000)$ at the level of significance less than $5 \%$. And this means that there is an effect of social responsibility activities on the companies' indebtedness. The table also shows that the level of significance of the impact of the disclosure of social activities on debt reached (.000) which means that there is an effect of social activities on indebtedness, while the level of significance of environmental activities has reached (.595) This indicates that there is no effect 
of environmental activities on the indebtedness of companies listed on the Amman Stock Exchange.

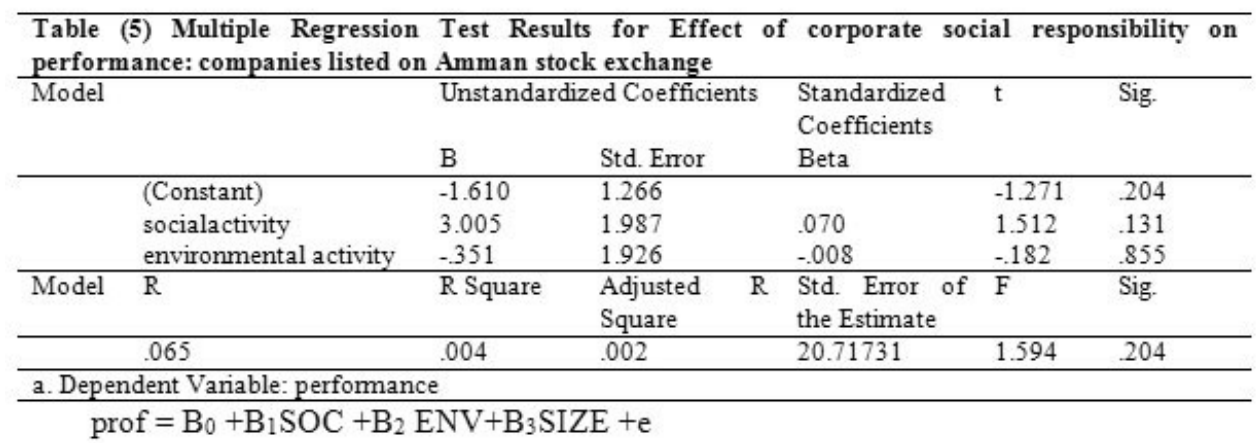

Table 5 shows that the level of significance of the impact of disclosure of social responsibility activities on performance in companies listed on the Amman Stock Exchange reached (204) at a level of significance greater than 5\%, this means that there is no impact of social responsibility activities on the performance of companies. The table also shows that the level of significance of the impact of the disclosure of social activities on performance has reached (131), As for the level of significance of environmental activities, it reached (855), and this indicates that there is no effect of social and environmental activities on the performance of companies listed on the Amman Stock Exchange.

\section{Discussion the Study Results}

This study aimed to divide social responsibility into community service and environmental activities on the company's debt and performance for companies listed on the Amman Stock Exchange, and the results of the study showed that there is an effect of social activities on debt, while there was no effect of social responsibility activities on the performance of companies. The absence of the effect of social activities can be limited to the performance of companies, that the community activities do not directly affect the performance of companies, as the expected costs of these activities may be greater than the benefits, in addition, the environment in which companies operate may be complex, which justifies higher costs to counter this environment, which negatively affects the performance of companies, also, the sample of the study consists of more than one industrial, service and financial sector, and the degree of interest of this sector in these activities may vary according to the nature of the sectors' work, the administration may also justify the decrease in the company's performance due to meeting social activities, where this reflects negatively on the performance of companies, and the results of this study were in agreement with many studies (Bilal et al, 2014) (Inoue \& Lee, 2011, Mahoney \& Roberts, 2007).

The results of the study also showed that there was no effect of environmental activities on the performance of companies listed on the Amman Stock 
Exchange, and this result can be explained by the fact that the study sample consists of more than one industrial, service and financial sector and the degree of interest of this sector in these activities may differ according to the nature of the work of those sectors whose activities may affect the environment, because spending on environmental activities is costly and may affect corporate profitability, and some chemical industrial companies may have a negative impact in terms of environmental pollution, where the results of this study were agreed with (Omar and others, 2014) (Inoue \& Lee, 2011 Kacperczyk, 2009).

This study also recommends encouraging laws and regulations to focus on social responsibility because of its long-term impact on society and the environment, especially as the world is now concerned with this field in developed countries.

\section{References}

Abdul-Razzaq, F. \& Al-Hindawi, R. (2011). "Extent of Disclosure of Elements of Social Responsibility for Public Joint Stock Companies, Case Study of Industrial Companies Listed on the Amman Stock Exchange for 2007-2008". Jordanian Journal of Business Administration, 7 (2): 294-273.

Al-Amry, S. \& Al-Ghalabi, T. (2008). Social Responsibility and Business Ethics Business and Society, Wael Publishing House, Amman, Jordan.

Bilal, O., Al-Shaar, I. \& Zaloum, N. (2014). The impact of the disclosure of social responsibility accounting on the financial performance of industrial companies, Jordanian public share, Administrative Science Studies, 41(2).

Boehe, D. \& Cruz, L. (2010). "Corporate social responsibility, product differentiation strategy and export performance", Journal of Business Ethics, 91(2): 325-346

Bremner, C. (2009). Sustainable tourism moves slowly in the right direction: Euro monitors International. London. http://www.euro monitor.com/ Sustainable Tourism Moves Slowly in the Right Direction

Cruz, L., Boehe, D. \& Ogasavara, M. (2015). “CSR-based differentiation strategy of export firms from developing countries: an exploratory study of the strategy tripod", Business \& Society, 54(6): 723-762

Dam, L. \& Scholtens, B. (2013). “Ownership Concentration and CSR Policy of European Multinational Enterprises", Journal of Business Ethics, 118: 117-126 
El Ghoula , A., Omrane, G., Chuck, C., Kwokb, D., \& Mishrac, R. (2011). Does corporate social responsibility affect the cost of capital?. Journal of Banking \& Finance, 35(9): 2388-2406

Fauzi, H., Mahoney, L. \& Rahman, A. (2007). The Link Between Corporate Social Performance and Financial Performance: Evidence from Indonesian Companies. Social and Environmental Accounting, 1(1): 149-159

Guthrie, J., Cuganesan, S. \& Ward, L. (2008). Industry specific social and environmental reporting: The Australian Food and Beverage Industry. Accounting Forum, 32:1-15

Harjoto, M., \& Jo, H. (2011). "Corporate Governance and CSR Nexus", Journal of Business Ethics, 100: 45-67

Henderson, J. (2007). Corporate social responsibility and tourism: hotel companies in Phuket, Thailand, after the Indian Ocean tsunami. International Journal of Hospitality Management, 26: 228-239

Hichem, K., Khaled, H., Imen, A. (2015). "The effect of national culture on the association between profitability and corporate social and environmental disclosure: A meta-analysis", Meditari Accountancy Research, 23 (3): 296-321, https://doi.org/10.1108/MEDAR-12-2014-0064.

Hirigoyen, G., \& Poulain-Rehm, T. (2015). Relationships between Corporate Social Responsibility and financial performance: What is the Causality?. Journal of Business \& Management, 4 (1), pp.18-43

Hossain, M. Islam, K. \& Andrew, J. (2006). Corporate social and environmental disclosure in developing countries: evidence from Bangladesh in Proceedings of the Asian Pacific Conference on International Accounting. Hawaii

Hu, Y., Zhu, Y., \& Hu, Y. (2016). “Does Ownership Type Matter for Corporate Social Responsibility Disclosure: Evidence from China”, Global Conference on Business and Finance Proceedings, 11(1): 183-197

Inoue, Y. \& Lee, S. (2011). Effects of different dimensions of corporate social responsibility on corporate financial performance in tourism-related industries. Tourism Management, 32: 790-804

Jain et al., (2007). An Analytical Study on Social Responsibility Performance Evaluation as an Accounting Measure of Management Efficiency, Al \& Society, 21(3): 251-266 
Jarboo, Y. (2007). The extent of applying the accounting measurement and disclosure for social responsibility in the financial statements in the companies in the Gaza Strip. Islamic University Journal, 15 (1): 281-239.

Jung, H. \& Kim, D. (2015). "Good neighbors but bad employers: two faces of corporate social responsible programs", Journal of Business Ethics. doi: 10.1007/s10551-015-2587-3.

Kacperczyk, A. (2009). With greater power comes greater responsibility? Takeover protection and corporate attention to stakeholders. Strategic Management Journal, 30: 261- 285

Katsioloudes, M. (2007). Corporate Social Responsibility: An Exploratory Study in the United Arab Emirates, S.A.M. Advanced Management Journal, Corpus Christi, 72 (4): 9-20

Mahoney, L. \& Roberts, R. (2007). Corporate social performance, financial performance and institutional ownership in Canadian firms. Accounting Forum, 31: 233-253.

Mobaideen, T. \& Al-Dhahrawi, M. (2017). The impact of the disclosure of extractive and mining industries companies listed on the Amman Stock Exchange on the costs of social responsibility on the financial performance of the sector, Journal of Saleh Kamel Center for Islamic Economics at Al-Azhar University, 22 (55): 182-222.

Mwangi, C., Jerotic, J. (2013). The Relationship between Corporate Social Responsibility Practices and Financial Performance of Firms in the Manufacturing, Construction and Allied Sector of the Nairobi Securities Exchange, International Journal of Business, Humanities and Technology, 3 (2).

Ndemanga, D. \& Koffi, E. (2009). Ownership Structure, Industry sector and Corporate Social Responsibility (CSR) practices: - The case of Swedish listed companies. Unpublished thesis, University of Gothenburg. Swedish.

Obby, P., Elisavet, M. \& Pauline, G. (2018). "Stakeholder interactions and corporate social responsibility (CSR) practices: Evidence from the Zambian copper mining sector", Accounting, Auditing \& Accountability Journal, https://doi.org/10.1108/AAAJ-04-2016-2540. 
The Effect of Corporate Social and environmental Responsibility....

Rahahleh, M. \& Sharairi, J. (2008). The extent of Social Responsibility Accounting Application in the Qualified Industrial Zones in Jordan, International management review, 4(2): 5-17.

Rashi, T. (2013). The Role of Adopting a Social Responsibility Approach in Creating and Supporting Entrepreneurship and Competitiveness in Business Administration, Paper presented to the Ninth World Scientific Conference on Islamic Economics and Finance, Turkey.

Ramanathan, R. \& Akanni, A. (2015). "The moderating effect of operations efficiency on the links between environmental performance and financial performance: the UK evidence", Asian Journal of Innovation and Policy, 4 (1): 76 102.

Saleh, M., Zulkifli, N., \& Muhamed, R. (2010). “Corporate Social Responsibility Disclosure and its Relation on Institutional Ownership - Evidence from Public Listed Companies in Malaysia", Managerial Auditing Journal, 25(6): 591-631.

Sunghee, L. \& Heungjun, J. (2016). "The effects of corporate social responsibility on profitability: The moderating roles of differentiation and outside investment", Management Decision, 54 (6): 1383-1406, https://doi.org/10.1108/MD-07-2015$\underline{0268}$

Tamkeen for Management and Development Consulting, (2007). International Institute for Environmental Economics and Industry, Saudi Companies and Social Responsibility Challenges and ways of progress: An Exploratory Study, Lander University - Sweden. 